\title{
Мотиваційні аспекти в формуванні самостійної фізичної активності у студентів медичного вищого навчального закладу
}

\author{
М. Н. Матяш, Л. І. Худенко \\ Київський медичний університет УАНМ, Київ, Україна
}

\begin{abstract}
Резюме. В статье рассматривается роль мотивационного аспекта в формировании самостоятельной физической активности у студентов медицинского вуза. Проведен анализ показателей, характеризующих мотивацию к самостоятельной активной физической деятельности. Для определения показателей, характеризующих мотивационные аспекты в формировании отношения к систематическим занятиям физической активностью, были использованы методы исследования изменений состояния самочувствия, активности и настроения.
\end{abstract}

Ключевые слова: мотивация, физическая активность, студенты.

Summary. The article discusses the role of the motivational aspect in the formation of an independent physical activity in students of medical universities. Analysis of indicators describing the motivation for independent active physical activity. To determine the parameters that characterize the motivational aspects at formation of the relation to the systematic employment physical culture techniques were used in a study of changes of health, activity and mood.

Key words: motivation, physical activity, students.

Роль мотивації студентів до занять фрізичною активністю - один із головних чинників у навчально-виховному процесі вищого навчального закладу (ВН3). На сучасному етапі розвитку освітніх закладів перед викладачами з фрізичного виховання постають важливі завдання - знайти засоби та шляхи підвищення мотивації у формуванні ставлення студентів до фрізичної культури та спорту, для активного, здорового способу та стилю життя.

Питання мотиву та цілі в діяльності особистості турбували людство вже давно. Наприклад, Сократ та Платон у своїх роботах вказували на властиві людині потреби, бажання, цілі. За однією із теорій, споживацька мотивація (Демокріт, Геракліт) вдоволення потреб розглядається, як основна рушійна сила до дій. Сучасні науковці також відзначають необхідність в особистісному розвитку та самовдосконаленні, що дає розуміння потреби в самоактуалізації й розвитку своїх потенційних можливостей і талантів. Самі знання про засоби та методи виконання не забезпечують умінь реального їх відтворення на практиці, без реальних вмотивувань до їх використання та самих дій.

Для визначення терміну «самоповага» У. Джеймс дає таку формулу:

Самоповага $=$ Успіх / Особистісні претензії.

Трактувати цей підхід можливо по-різному: як прагнення до мотивації дефріциту чи мотивації до особистісного зростання. Зрозуміло, що мотив $\epsilon$ ключовим фактором, який збуджуює свідомість до діяльності.

Мотив формується на основі потреб. Специфрічні людські потреби виникають із видозмінених напрямів розвитку індивіда. А. Маслов виділяв сім категорій людських потреб:

1) фрізіологічні - свідчать про порушення гомеостазу організму; ності;

2) безпека - необхідна для відчуття впевне-

3) любов - проявляється бажанням любити та бути любимими;

4) визнання, повага та компетенція;

5) самореалізація;

6) пізнавальна діяльність;

7) естетичні потреби.

Щодо питання ієрархії потреб можна сказати, що хоч естетичні потреби і залежать від задоволення основних потреб організму, але таке надмірне задоволення не призводить до розвитку інтересів в естетичній сорері.

Спортивні майданчики чи басейни потрібно шукати (притому не скрізь $€$ можливість ними скористатись), а от доступність алкогольних та тютюнових виробів підтримується індустрією потреб у товарах та послугах. Можна вважати причиною відсутності культури по відношенню до своєї особистості - у владі. Адже владою 
та носіями влади $€$ законодавчі та виконавчі структури, які на сьогодні дещо безликі, тобто відсутня особиста зацікавленість в ефективності дії, можливо, навіть ідеально-досконалих законів (вже і прийнятих), по досягненню мети в особистому здоров'ї громадян. Тому самоорганізація особистості - найбільш доступна фрорма для здорового, фрізично активного способу життя.

Морально застарілі програми 3 фрізичного виховання (ще 3 дитсадівського періоду до підготовки у ВНЗ) та відсутність послідовних комплексних державних політичних засобів щодо зміцнення здоров'я населення, негативні моменти на шляху всебічного розвитку нації заважають розвиненню інфраструктури для занять фрізкультурою, спортом та туризмом.

Мотивація - це сукупність рушійних сил, що спонукають людину до цілеспрямованої діяльності. Мотиваційна сорера формується за допомогою віри, ідеалів, цінностей, потреб, мотивів, цілей, інтересів, ідей тощо. Необхідно, розуміючи типологію особистості, сорормувати мотиваційно-ціннісне ставлення до свого розвитку у студентів-медиків.

Щоб особистість оцінила важливість у дієвій активності, потрібна власна впевненість у особистісній важливості. Факторами, що стимулюють до будь-якої активності та впливають на впевненість, є віра у свої сили (корисний досвід 3 дитинства, коли ми в захваті від своїх досягнень, пізнань можливостей свого тіла) та копіювання важливого об'єкта - вчителя - як прикладу для наслідування.

Важливий вплив на мотиваційну складову чинить емоційний компонент. Так, позитивне підкріплення у фрормі заохочення (схвалення) від викладача (як авторитетної особи) додає впевненості в своїх силах. Від такого підкріплення особистість отримує здатність більше докладати зусиль для досягнення мети. Важливе й розуміння того, що поставлено вивірені, чіткі цілі, а також розуміння, що регулярний підхід до дій та осмислена особистісна позиція важливіша від талантів і особливих природних даних. Ціль - це те, до чого прагнеш, чого намагаєшся досягнути. Ціллю може бути не тільки об'єкт, предмет, а що важливіше - діяльність.

Існують і фрактори, що заважають позитивному вмотивуванню особистості. Однією з причин невідвідування занять $€$ внутрішнє побоювання «..я погано буду виглядати у спортивному одязі, бо не маю спортивної фрігури», та неприязне ставлення до огрядних у соціумі - це помилкові особистісні вірування. Вони зміняться на позитивні, життєстверджувальні 3 поступовим зростанням нових, натренованих компетенцій. Фізичне виховання $€$ не тільки праця над формами, а й розвиток морально-вольових якостей, що знадобиться при оволодіванні будь-якою професією.

Для лікаря, який повинен бути взірцем для наслідування - тому що він $€$ носієм знань та вмінь - головним $€$ почати з себе на шляху до саморозвитку цілісної особистості. Соціальноекономічні зміни в суспільстві, що можна сприймати як негативні чи позитивні, позбавили наш теперішній соціум «духу колективізму», але ще $€$ надія на взаємну індукцію, і позитиві наміри та цілеспрямовані зусилля будуть нагороджені позитивними змінами.

В той же час, з нашої точки зору, актуальним $€$ вирішення проблем розвитку мотивації серед студентів шляхом вибору засобів і методів (залежно від рівня фрізичної та психологічної готовності студентів), з урахуванням їх потреб, щоб підвищити свій рівень фрізичної підготовки задля здорового способу життя, в залежності від терміну та етапу навчання у ВНЗ.

Мета дослідження - вивчити мотиваційні аспекти формування у студентів медичних ВНЗ самостійної фрізичної активності. Проаналізувати показники, що характеризують мотивацію до самостійної активної фрізичної діяльності.

Матеріали і методи. Дослідження проводилось $з$ квітня по листопад 2013 р. зі студентами Київського медичного університету УАНМ, що систематично займались фрізичними вправами та відвідували заняття з фрізичної культури відповідно до програми занять в університеті. В дослідженні взяли участь 137 студентів у віці 18-25 років. Мотивацію щодо систематичних занять фрізичною активністю і показники, що характеризують зміни в самопочутті та настрої, аналізували (до та після занять) за допомогою методики САН. Для аналізу об'єктивної інформації про рівень мотиваційної спрямованості в діяльності студентів було використано такі методи: анкетний тест Т. Елерса «Виявлення мотивації до успіху» (тест враховує три основні мотиваційні вектори, які $\epsilon$ вирішальними в характері взаємозв'язків активної діяльності та мотивації до досягнень); методику «Мотиви до занять фрізичною активністю» ( яка визначає домінуючі мотиви до навчально-тренувальних заходів, та дозволяє отримати рейтинг за ступенем їх важливості); тест Є. Ільїна «Визначення потреби в активності», що демонструє рівень внутрішнього енергетичного потенціалу; методику Ю. В. Шаболтаса «Мотиви занять спортом» - для виявлення домінуючих цілей; тест Люшера - дослідження емоційної складової. 


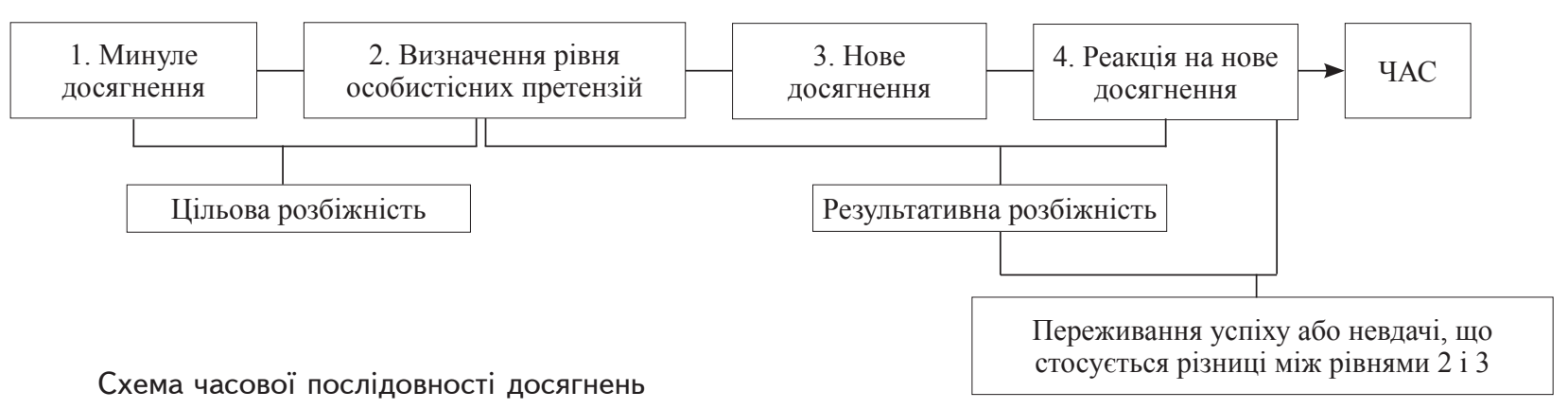

Результати та їх обговорення. В процесі дослідження мотиваційних аспектів у формуванні самостійної фізичної активності у студентів медичного ВНЗ та аналізу показників, що характеризують мотивацію до самостійної активної фрізичної діяльності, найбільш інформативними виявились: тестовий метод Т. Елерса «Виявлення мотивації до успіху»; методика «Мотиви до занять фрізичною активністю».

Всі студенти на стадії вступу, отримавши перший результат та вникнувши у специфіку навчання в університеті, яка відрізняється методологічними підходами від шкільної освіти, переживали ситуацію цільової невідповідності через різницю між досягненнями досліджуваного i його особистісними претензіями, що мають відношення до подальших досягнень. Часову послідовність результатів, які досягаються, та рівень особистісних претензій наведено на схемі (див. вище).

Враховуючи, що будь-який мотив $є$ рушійною силою до різних видів діяльності, проведено аналіз основних аспектів вмотивованої поведінки у студентів, які відвідували заняття з фрізичної культури за програмами університету, та систематично займались фрізичними вправами в тренажерних залах і на спортивних майданчиках.

Після обробки результатів дослідження за методикою «Мотиви до занять фрізичною активністю» отримали показники, що визначають ставлення студентів до фрізичної активності (табл. 1).

Орієнтацію на мотив «емоційне задоволення» обрали 17,8 \% студентів і визначили це, як задоволення від рухового навантаження, відчуття напруження м'язів, що надихає і дає змогу відчути хвилювання і в той же час - впевненість у можливості реалізувати свій потенціал. 3 мотивів соціального самоствердження 13,9 \% студентів прагнуть проявити себе в процесі рухової активності і розглядають свої досягнення з точки зору особистого престижу, самоповаги.

Мотив фрізичного самоствердження - y 4,5 \% студентів, які висловили бажання до фрізичного розвитку, формування характеру. До соціально-емоційної мотивації прагнуть 8,1% студентів, котрі мають схильність до спортивних занять через їх високу емоційність і неформальний підхід, можливість отримати позитивні релаксаційні відчуття та почуття незалежності від соціуму. Соціально-моральні мотиви домінували у $3,8 \%$ студентів, які розглядають їх у контексті прагнення до успіху своєї команди, для чого необхідно наполегливо тренуватися, мати добрий контакт із партнерами та тренером.

Мотив досягнення успіху у фрізичних заняттях $(12,7 \%)$ виражається в гонитві за успіхом, покращенні особистісних якостей та власних спортивних результатів. Спортивно-когнітивні мотивації $(2,5 \%)$ - бажання до вивчення питань технічної та тактичної підготовки, розуміння принципів методик тренування. Раціонально-вольовий (рекреаційний) мотив підтримують 11,9 \% студентів, які готові працювати для компенсації нестачі рухової активності при підвищеному розумовому навантаженні.

Мотив підготовки до професійної діяльності спостерігаються в 19 \% суб'єктів і розглядається як бажання займатися фрізичною культурою та спортом і краще підготуватися до обраної профресії - лікаря зі спортивної медицини. Мотив

ТАБЛИЦЯ 1 - Розподіл студентів відповідно до різновиду мотивів до занять фізичною активністю

\begin{tabular}{|l|c|c|}
\hline \multicolumn{1}{|c|}{ Мотив } & Частота, \% & $\begin{array}{c}\text { Кількість } \\
\text { студентів }\end{array}$ \\
\hline Емоційне задоволення & & 25 \\
\hline Соціальне самоствердження & 13,8 & 19 \\
\hline Фізичне самоствердження & 4,5 & 6 \\
\hline Соціально-емоційний & 8,1 & 11 \\
\hline Соціально-моральний & 3,8 & 5 \\
\hline Досягнення успіху & 12,7 & 17 \\
\hline Спортивно-когнітивний & 2,5 & 3 \\
\hline $\begin{array}{l}\text { Раціонально-вольовий } \\
\text { (рекреаційний) }\end{array}$ & 11,9 & 16 \\
\hline $\begin{array}{l}\text { Підготовка до профресійної } \\
\text { діяльності }\end{array}$ & 19 & 27 \\
\hline Громадсько-патріотичний & 58 & 137 \\
\hline Усього & 100 & 8 \\
\hline
\end{tabular}


громадсько-патріотичний проявили 5,8 \% студентів, як прагнення до фрізичного вдосконалення для успішного виступу у змаганнях, щоб підтримати престиж навчального закладу, міста, країни.

Таким чином, в порядку їх значущості, найвищий відсоток студентів вмотивовують заняття з фрізичної культури в рамках підготовки до майбутньої кар'єри, наступні мотиви мали більш емоційний характер і прагнення до самоствердження. Найнижчий рівень спостерігався в групах студентів із спортивно-когнітивною та соціально-моральною мотивацією.

Динаміка мотивації для всіх параметрів показує індивідуальне ставлення студентів до свого фрізичного стану і здоров'я. У той же час, певною мірою це можливе для визначення і особистої орієнтації на життєві цінності студентів, які націлені на перспективу в подальшій роботі, сподіваючись тільки на свої індивідуальні здібності, інші студенти вбачають в своїй кар'єрі допомогу з боку колег, друзів та ін. По суті мотиви, що вивчалися, це своєрідні орієнтири не тільки в сорері фрізичної активності, але й нові життєві установки, що виховують особистість студента.

Лідерські позиції мотивів до професійної діяльності та емоційного задоволення показують бажання студентів досягати високих результатів і в інших видах діяльності - освіті, роботі, - що можливе через зміцнення свого фрізичного потенціалу за рахунок підвищення рівня фрізичної активності. Принцип комплексності говорить про те, що непотрібних предметів, які викладають в університеті, не буває, а весь процес навчання $є$ цілісним і фрормується в поєднанні різних знань.

Для визначення, чи залежить мотиваційна направленість учасників дослідження від рівня їх фрізичної активності на довузівському етапі життя, та, діагностуючи студентів на виявлення мотивації підготовки до професійної діяльності, використовували анкетний тест Т. Елерса.

Високий рівень фрізичної активності мають студенти, які займаються на медичному факультеті за програмою «Лікувальна справа» (з варіативною компонентою «спортивна медицина»). Звичайний рівень фрізичної активності - у студентів, які навчаються на стоматологічному й медичному фракультетах та відвідують заняття 3 фрізичної культури відповідно до програми університету. Низький рівень фрізичної активності - у

\section{Література}

1. Добровольська Н. О. Оптимізація фрізичного стану студентів шляхом самостійних тренувань: навч. посіб. / Н. О. Добровольська. - Донецьк, 1994. - 179 с.
ТАБЛИЦЯ 2 - Показники мотивації підготовки до професійної діяльності у студентів з різним рівнем фізичної активності

\begin{tabular}{|l|c|c|l|}
\hline \multirow{2}{*}{$\begin{array}{c}\text { Рівень фізичної актив- } \\
\text { ності }\end{array}$} & \multicolumn{3}{|c|}{ Домінуюча мотивація, бал } \\
\cline { 2 - 4 } & чоловіки & жінки & загальні дані \\
\hline Група I - високий & $19,5 \pm 0,7$ & $17,2 \pm 0,4$ & $16,8 \pm 0,8$ \\
\hline Група II - звичайний & $17,1 \pm 0,1$ & $17,3 \pm 1,2$ & $17,0 \pm 1,2$ \\
\hline Група III - низький & $15,6 \pm 0,6$ & $14,4 \pm 0,9$ & $13,3 \pm 0,7$ \\
\hline Середнє значення & $14,6 \pm 0,8$ & $16,6 \pm 1,2$ & $14,7 \pm 1,2$ \\
\hline
\end{tabular}

студентів, які займаються фрізичною активністю, тільки відвідуючи заняття з фрізичної культури відповідно до програми університету.

Орієнтуючись на результати дослідження, порівнюючи показники домінуючої мотивації, можна зробити висновок (табл. 2), що найбільш високий рівень мотивації у студентів чоловічої статі в групі I - 19,5 бала, а серед студентів жіночої статі в групі II - 17,3 бала, середнє значення показників домінуючої мотивації у студенток вище ніж у студентів чоловічої статі.

\section{Висновки:}

1. Мотивація студентів до фрізичної діяльності обумовлена внутрішніми та зовнішніми фракторами: зовнішніми - наявністю матеріальної бази, внутрішніми - психоемоційними та фрізіологічними індивідуальними особливостями, що впливають на логічне й емоційно осмислене прийняття студентами рішень щодо саморозвитку.

2. Найвищий відсоток студентів мотивують заняття з фрізичної культури в рамках підготовки до майбутньої кар'єри, наступні мотиви мали більш емоційний характер і як мету - прагнення до самоствердження. Найнижчий рівень спостерігався в групах зі спортивно-когнітивної мотивацією та соціально-моральною мотивацією студентів.

3. Мотив лідерської позиції до профресійної діяльності та емоційного задоволення показує бажання студентів досягати високих результатів і в інші видах діяльності - освіті, роботі, для чого потрібне зміцнення свого фрізичного потенціалу за рахунок підвищення рівня фрізичної активності.

4. Порівнюючи показники домінуючої мотивації, можна зробити висновок, що найбільш високий рівень мотивації у студентів чоловічої статі з групи I - 19,5 бала, а серед студентів жіночої статі - у групі II - 17,3 бала.

\section{References}

1. Dobrovolska N. O. Optimization of the physical condition of students through self training: manual training / N. O. Dobrovolska. - Donetsk, 1994. - 179 p. 
2. Карпман В. Л. Тестирование в диагностике физической работоспособности и функциональной готовности спортсменов: учеб. для ин-тов физ. культуры / В. Л. Карпман. - М.: Физкультура и спорт, 1987. - 168 с.

3. Крамской С. И. Образ жизни и здоровье студентов: проблемы, анализ, опыт, рекомендации / С. И. Крамской, В. П. Зайцев // Физ. культура и здоровье. - 2006. № 1(7). - С. 38-41.

4. Куриш В. Мотиваційна спрямованість студентів першого курсу до занять фрізичними вправами / В. Куриш, М. Лук'янченко // Фізичне виховання студентів вищих навчальних закладів: здобутки, проблеми та шляхи їхнього вирішення у контексті вимог Болонської декларації: матеріали Всеукр. наук.-практ. конф. - К., Нац. ун-т «Києво-Могилянська академія», 2007. - С.159-161.

5. ЛобаноВ А. П. Самостоятельная работа студентов в контексте компетентносного похода / А. П. Лобанов // Организация самостоятельной работы на факультете вуза : материалы Междунар. науч.-практ. конф. Минск, 16-17 ноября 2006 г.- Минск: БГУ, 2006. - С. 35-38.
2. Karpman V. L. Testing of diagnostic of physical performance and functional readiness of athletes: textbook for institutes of physical culture / V. L. Karpman. - Moscow: Fyzkultura i sport, 1987. - 168 p.

3. Kramskoj S. I. Lifestyle and health of students: problems, analysis, experience, recommendations / S. I Kramskoj, V. P. Zaitsev // Fyzkultura s zdorovie. - 2006. N 1(7). - P. 38-41

4. Kurish V. Motivational orientation of first-year students to exercise / V. Kurish, M. A. Luk'yanchenko // Physical Education students in higher education: Achievements, Problems and their solutions in the context of the Bologna Declaration. Materials of the All-Ukrainian scientific - practical conference. - Kyiv: National University of «Kievo-Mogilyanska akademiya», 2007. - P. 159-161

5. Lobanov A. P. Independent work of students in the con-text of the competence approach // Organization of independent work at the Faculty of University College: Materials of Intern. Scientific Conference. - Practice. conf. Minsk, 1617 November 2006, - Minsk: BSU, 2006. - P. 35-38 